Scientia Agricola

http://dx.doi.org/10.1590/0103-9016-2014-0044

\title{
Waterlogging-induced changes in fermentative metabolism in roots and nodules of soybean genotypes
}

\author{
Junior Borella ${ }^{1}$, Luciano do Amarante ${ }^{1,2}$, Denise dos Santos Colares de Oliveira ${ }^{2 *}$, Ana Claudia Barneche de Oliveira ${ }^{3}$, Eugenia \\ Jacira Bolacel Braga ${ }^{1}$
}

${ }^{1}$ Federal University of Pelotas/Institute of Biology - Dept. of Botany.

${ }^{2}$ Federal University of Pelotas/Chemical Sciences, Pharmaceutical and Food Center, C.P. 354 - 96160-000 Pelotas, RS - Brazil.

${ }^{3}$ Brazilian Agricultural Research Corporation/Embrapa Temperate Climate Agricultural Research Center, BR 392, km 78 - 96010-971- Pelotas, RS - Brazil.

*Corresponding author<colares@ufpel.edu.br>

Edited by: Daniel Scherer de Moura

Received February 03, 2014

Accepted April 28, 2014

\begin{abstract}
Waterlogging blocks the oxygen supply to the root system which inhibits respiration, and greatly reduces the energy status of cells that affect important metabolic processes. This study evaluated fermentative metabolism and carbohydrate contents in the root system of two soybean (Glycine max L. Merril) genotypes under hypoxic and post-hypoxic conditions. Nodulated plants (genotypes Fundacep 53 RR and BRS Macota) were grown in vermiculite and transferred to a hydroponic system at the reproductive stage. The root system was submitted to hypoxia by flowing $\mathrm{N}_{2}$ (nitrogen) gas in a solution for 24 and $72 \mathrm{~h}$. For recovery, plants returned to normoxia condition by transfer to vermiculite for 24 and $72 \mathrm{~h}$. Fermentative enzyme activity, levels of anaerobic metabolites and carbohydrate content were all quantified in roots and nodules. The activity of alcohol dehydrogenase, pyruvate decarboxylase and lactate dehydrogenase enzymes, as well as the content of ethanol and lactate, increased with hypoxia in roots and nodules, and subsequently returned to pre-hypoxic levels in the recovery phase in both genotypes. Pyruvate content increased in nodules and decreased in roots. Sugar and sucrose levels increased in roots and decreased in nodules under hypoxia in both genotypes. Fundacep RR 53 was more responsive to the metabolic effects caused by hypoxia and post-hypoxia than BRS Macota, and it is likely that these characteristics contribute positively to improving adaptation to oxygen deficiency.
\end{abstract}

Keywords: Glycine max, oxygen deficiency, enzyme activities, anaerobic metabolites, sugars

\section{Introduction}

Soil waterlogging is a common abiotic stress worldwide in cultivated areas and influences the composition and productivity of soybean (Glycine max L. Merril) and most crops species (Jackson and Colmer, 2005; Githiri et al., 2006; Sairam et al., 2009; Kokubun, 2013). In waterlogged soils, gas exchanges between root systems and soil porous spaces are limited due to oxygen diffusion resistance that is around 10,000 times higher in water than in the air (Armstrong et al., 1994; Dongen et al., 2003; Zabalza et al., 2009; Bailey-Serres et al., 2012).

Decrease in the oxygen level is the main factor that causes stress, leading to a chain signaling that unleashes a series of metabolic changes (Horchani et al., 2009), such as $\mathrm{N}$ metabolism and interconversion of amino acids (Puiatti and Sodek, 1999; Oliveira et al., 2013), changes in carbohydrates levels and energetic metabolism (Sousa and Sodek, 2002a), in an effort to secure plant survival and growth when exposed to hypoxic stress (Geigenberger, 2003). Anaerobic metabolism is activated under low oxygen concentration and as a consequence, there is a significant decrease in energy production that is derived mainly from glycolysis in contrast to oxidative phosphorylation (Kumutha et al., 2008; Horchani et al., 2009; Sairam et al., 2009; Zabalza et al., 2009). Plant survival under these conditions depends almost exclusively on anaerobic metabolism (Sousa and Sodek, 2002a).
Due to the lack of $\mathrm{O}_{2}$ as the final electron acceptor, there is an accumulation of intermediates of Krebs cycle, $\mathrm{NAD}(\mathrm{P})^{+}$levels decrease, pyruvate accumulate and ATP levels decrease. All these modifications act as a signal for further adaptive responses (Horchani et al., 2009). Enzymes of two important pathways are induced under anaerobic conditions: lactic fermentation is a one-step reaction from pyruvate to lactate, catalyzed by lactate dehydrogenase (LDH) with the regeneration of $\mathrm{NAD}^{+}$. Ethanolic fermentation is a two-step process regenerating $\mathrm{NAD}^{+}$in which pyruvate is first decarboxylated to acetaldehyde by pyruvate decarboxylase (PDC), and acetaldehyde is subsequently converted to ethanol by alcohol dehydrogenase (ADH) (Tadege et al., 1999; Zabalza et al., 2009).

Although many studies have been carried out to clarify the effects of oxygen deficiency in plants, few studies are related to nodulated plants, especially soybean. This study aimed to characterize anaerobic metabolism through alterations of lactic and alcoholic fermentation enzymes, anaerobic metabolites and carbohydrate allocation in roots and nodules of two genotypes of soybean under hypoxia and post-hypoxic conditions.

\section{Materials and Methods}

Plant material, growth conditions and treatments Soybean plant cultivars 'Fundacep $53 \mathrm{RR}^{\prime}$ and 'BRS Macota' were grown in greenhouse under natural light and temperature conditions. Plants were cultivated 
in 3 L-pots (three plants per pot) in vermiculite and irrigated twice a week with $250 \mathrm{~mL} \mathrm{~N}$-free nutrient solution, as has been previously described (Lima and Sodek, 2003). Plants were inoculated when the cotyledons were fully open, by applying $2 \mathrm{~mL}$ suspension of Bradyrhizobi-

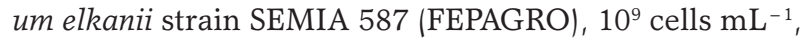
around the stem of each plant on two occasions at three day intervals. Treatments were initiated with plants at stage R2 [for stage definitions, see Fehr et al. (1971); R2 = flowering (early reproductive stage)]. For the hydroponic treatment, plants were removed from pots and the root system was washed in tap water to remove the vermiculite before transferring to 3 L-pots (three plants per pot) containing $\mathrm{N}$-free nutrient solution at one-third of normal strength. The whole root system (including the nodules) was kept submersed in the nutrient solution. In experiments, the nodulated root system was subjected to hypoxia by flushing $\mathrm{N}_{2}$ gas $\left(99.99 \% \mathrm{~N}_{2}\right)$ for 24 and $72 \mathrm{~h}$. Oxygen concentration in solution was monitored with an oxygen meter (Handylab OX1). For recovery, plants were returned for 24 and $72 \mathrm{~h}$ to 3 -L pots containing vermiculite as substrate. Plants kept in vermiculite were used as controls. Roots or nodules collected from the three plants of each pot were pooled to form a single replicate for analysis and stored frozen $\left(-80^{\circ} \mathrm{C}\right)$ until analyzed for metabolites and enzymatic activities.

\section{Statistical analyses}

Each treatment consisted of four replicates and each replicate consisted of one pot containing three plants (material pooled), in a fully randomized design. The data were analyzed by one-way analysis of variance (ANOVA). When $F$ was significant the treatments means were compared by Tukey's test $(p \leq 0.05)$. Statistical analyses were performed using the SAS 8.0 statistical software program (SAS Institute Inc. Cary, NC, USA).

\section{Enzymatic activities assays}

Enzymes activities in roots and nodules were determined as indicated in the text. Frozen plant material was pulverized with liquid $\mathrm{N}_{2}$ in a cool mortar and homogenized with $5 \%$ (w:fw) polyvinylpolypyrrolidone and cold enzyme extraction buffer $(50 \mathrm{mM}$ Tris/ $\mathrm{HCl} \mathrm{pH}$ 7.5 containing $1 \mathrm{mM}$ DDT - dithiothreitol). All experiments were carried out at $4{ }^{\circ} \mathrm{C}$. The homogenate was centrifuged at $12,000 \mathrm{x}$ g for $20 \mathrm{~min}$, and an aliquot of the supernatant was desalted using a PD10 column. The eluted protein fraction was specifically assayed for $\mathrm{ADH}$ activity (EC 1.1.1.1), PDC activity (EC 4.1.1.17) and LDH activity (EC 1.1.1.17). Total protein content of the enzyme extract was measured as described by Bradford (1976). The enzymatic assays were performed spectrophotometrically by monitoring the oxidation of $\mathrm{NADH}$ at $340 \mathrm{~nm}$ for $2 \mathrm{~min}$ at $30^{\circ} \mathrm{C}$. The $\mathrm{ADH}$ assay was monitored in acetaldehyde ethanol direction in $1.5 \mathrm{~mL}$ reaction mix containing $50 \mathrm{mM}$ buffer (nodule: Tris- $\mathrm{HCl} \mathrm{pH}$ 7.5; root: K-phosphate $\mathrm{pH} 7.0$ ), $0.2 \mathrm{mM} \mathrm{NADH}$, sample and $5 \mathrm{mM}$ acetaldehyde to initiate the reaction (Hanson et al., 1984). The PDC assay was monitored in pyruvate $\rightarrow$ ethanol direction in $1.5 \mathrm{~mL}$ reaction mix containing 50 mM MES buffer (nodule: $\mathrm{pH}$ 6.0; root: $\mathrm{pH} 6.5$ ), 0.2 $\mathrm{mM} \mathrm{NADH}, 0.5 \mathrm{mM}$ thiamine pyrophosphate, $1 \mathrm{mM}$ magnesium chloride $\left(\mathrm{MgCl}_{2}\right), 20 \mathrm{mM}$ oxamic acid, 10 units of $\mathrm{ADH}$, sample and $10 \mathrm{mM}$ Na-pyruvate to initiate the reaction (Hanson et al., 1984). The LDH assay was monitored in pyruvate $\rightarrow$ lactate direction in $1.5 \mathrm{~mL}$ reaction mix containing $50 \mathrm{mM}$ buffer (nodule: Tris- $\mathrm{HCl}$ $\mathrm{pH}$ 7.5; root: K-phosphate $\mathrm{pH} 7.0), 0.2 \mathrm{mM}$ NADH, 3 $\mu \mathrm{M}$ potassium cyanide (KCN), $4 \mathrm{mM}$ 4-methylpyrazole, sample and $10 \mathrm{mM} \mathrm{Na-pyruvate}$ to initiate the reaction (Hanson and Jacobsen, 1984).

\section{Metabolites analyses}

Ethanol, lactate and pyruvate were extracted from the roots and nodules. Samples were frozen with liquid $\mathrm{N}_{2}$ and then ground with an addition of $10 \mathrm{~mL} 6 \%$ perchloric acid. The homogenates were centrifuged for 20 $\min$ at $3,000 \times \mathrm{g}$ at $0{ }^{\circ} \mathrm{C}$. Supernatants were neutralized with cold $5 \mathrm{M}$ potassium carbonate in an ice bath. Metil orange $\left(0.5 \mathrm{~g} \mathrm{~mL}^{-1}\right)$ was used to monitor $\mathrm{pH}$. Potassium perchlorate was removed by centrifugation (Kolb and Joly, 2009). Ethanol and lactate were determined enzymatically, using test kits (Boehringer, Mannheim, Germany). Pyruvate was determined by enzymatic methods, as described by Kolb and Joly (2009).

\section{Carbohydrate Analyses}

Carbohydrates were extracted from the roots and nodules. Low molecular weight compounds /reducing sugars and sucrose) were extracted with MCW (methanol, chloroform, water: 12/5/3) for $24 \mathrm{~h}$ using $10 \mathrm{~mL}$ $\mathrm{g}^{-1}$ fresh weight of tissues and the solution was further centrifuged (30 min, $600 \mathrm{x} \mathrm{g}$ ). The aqueous phase was recovered following phase separation by centrifugation (30 $\mathrm{min}, 600 \times \mathrm{g}$ ) after addition of chloroform (1 mL) and water $(1.5 \mathrm{~mL})$ to $4 \mathrm{~mL}$ of supernatant. The aqueous phase solution was then reduced to a known volume by evaporation at $38{ }^{\circ} \mathrm{C}$ and kept frozen until analysis (adapted from Bieleski and Turner, 1966). Starch and water-soluble polysaccharides (WSP) were extracted by centrifugation (30 $\mathrm{min}, 600 \times \mathrm{g}$ ) from the residues after MCW extraction, with $10 \%$ trichloroacetic acid for WSP followed by $30 \%$ perchloric acid for starch as described by McCready et al., (1950). Determinations of total soluble sugars (TSS) and WSP (Graham and Smydzuk, 1965), sucrose (Handel, 1968) and starch (McCready et al., 1950) were carried out on the appropriate tissue extracts.

\section{Results}

\section{Oxygen levels of the nutrient solution}

Oxygen level of the nutrient solution, under normoxia was $6.37 \mathrm{mg} \mathrm{L}^{-1}$, in both genotypes decreasing abruptly to $0.53 \mathrm{mg} \mathrm{L}^{-1}$ in $6 \mathrm{~h}$ after the beginning of $\mathrm{N}_{2}$ gas flushing $72 \mathrm{~h}$ into the experiment, characterizing hypoxia (Figure 1). 


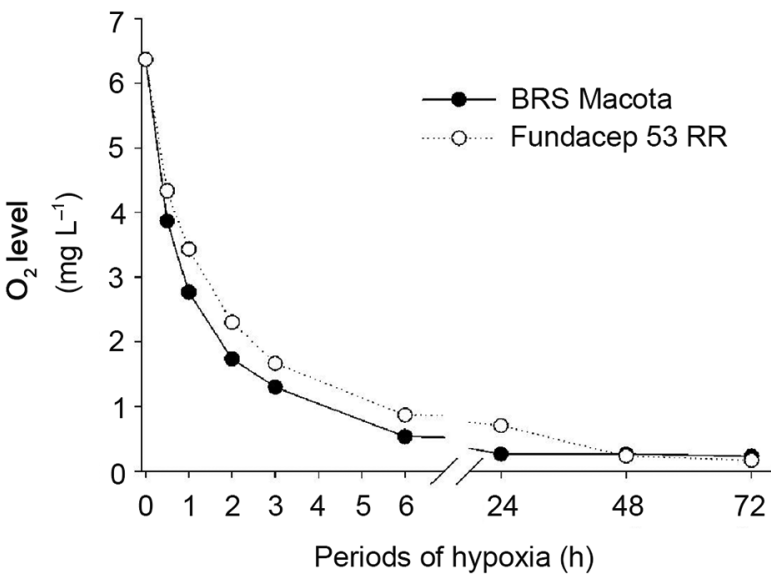

Figure 1 - Oxygen levels in hydroponic solution of soybean genotypes (Fundacep 53 RR and BRS Macota) in normoxia ( $0 \mathrm{~h}$ ) and after induction of hypoxia for $72 \mathrm{~h}$ (1-72 h).

\section{Enzymatic activity}

Fermentative enzyme activities in roots and nodules of soybean cultivars Fundacep 53 RR and BRS Macota were strongly influenced by hypoxia and post-hypoxia conditions (Figures 2 and 3). Alcohol dehydrogenase activity $(\mathrm{ADH})$ in the roots increased $(p<0.05)$ in relation to control with hypoxia at $24 \mathrm{~h}$, increasing substantially at $72 \mathrm{~h}$ of hypoxia for both genotypes. ADH levels decreased with the normoxia return, and BRS Macota took longer time in relation to Fundacep $53 \mathrm{RR}$ to recover (Figure 2A).

Pyruvate decarboxylase activity (PDC) was similar in relation to hypoxia effects on roots of both genotypes, with an increase under hypoxia and decrease in activity when returned to normoxia. However, PDC activity in Fundacep $53 \mathrm{RR}$ took longer to increase in hypoxia compared to BRS Macota and decreased faster to levels around control levels (Figure 2B). Lactate dehydrogenase activity ( $\mathrm{LDH})$ in roots of both genotypes increased, similar to the other enzymes under hypoxia ( 24 and $72 \mathrm{~h}$ ) and returned to levels around control levels after $72 \mathrm{~h}$ of recovery (Figure $2 \mathrm{C}$ ).

In nodules, fermentative enzymes activities from genotypes Fundacep 53 RR and BRS Macota were similar to the roots under hypoxia. Nevertheless, with the return to normoxia roots were more effective. ADH activity in nodules of Fundacep $53 \mathrm{RR}$ increased with the beginning of hypoxia and increased even more with the return to normoxia after $24 \mathrm{~h}$ of recovery. At $72 \mathrm{~h}$ of recovery ADH activity decreased to the level of the other treatments ( $24 \mathrm{~h}-\mathrm{H}, 72 \mathrm{~h}-\mathrm{H}$ and $24 \mathrm{~h}-\mathrm{R})$, still not recovering activity at control levels (Figure 3A). ADH activity in BRS Macota increased $(p<0.05)$ during hypoxia. Although there was a decrease of ADH activity with the recovery, the activity levels were kept high even at $72 \mathrm{~h}$ after returning to normoxia (Figure 3A).

PDC activity in Fundacep 53 RR nodules was similar to $\mathrm{ADH}$, increasing with hypoxia at 24 and $72 \mathrm{~h}$. Even

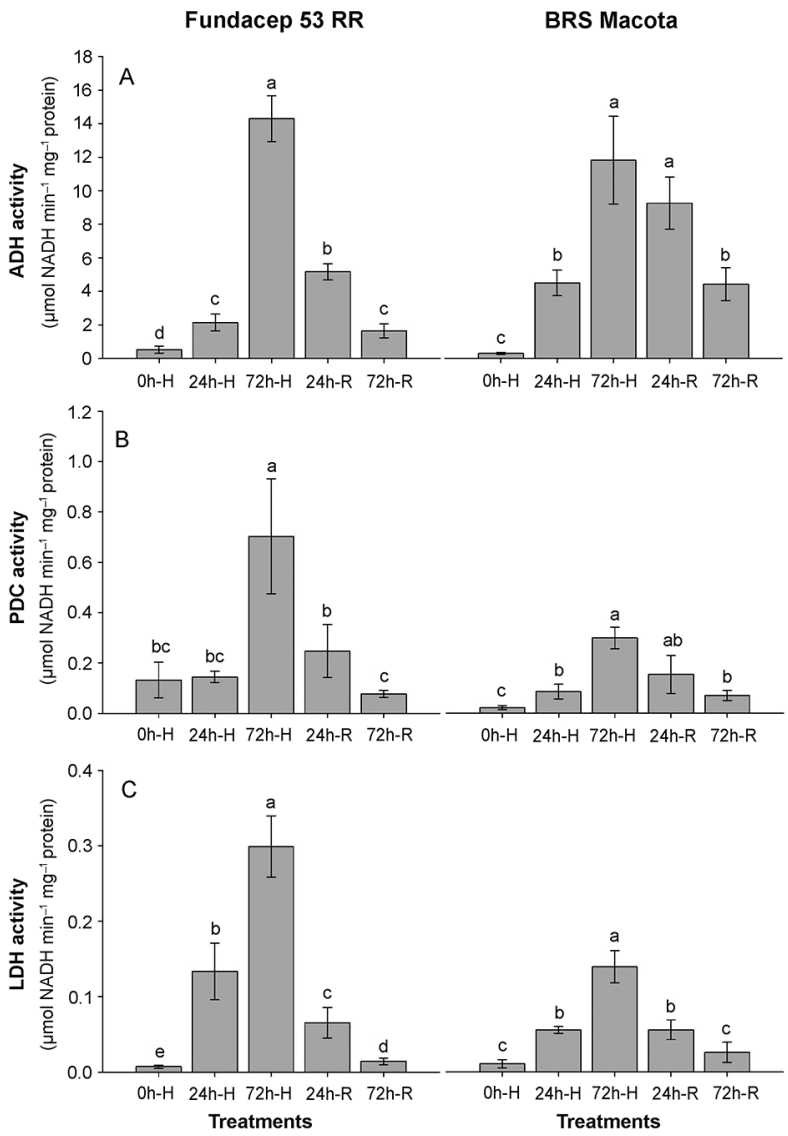

Figure 2 - Enzyme activities from roots of soybean genotypes (Fundacep 53 RR and BRS Macota) as induced by hypoxia and posthypoxia conditions. Alcohol dehydrogenase - ADH (A), pyruvate decarboxylase - PDC (B) and lactate dehydrogenase - LDH (C). Hypoxia (Oh-H, 24-H and 72-H) and recovery (24h-R and 72h-R). The bars mean value \pm SD as determined from four biological replicates. Values that differ according to a one-way ANOVA ( $p$ $\leq 0.05$ ) and Tukey posthoc test are marked with different small letters.

though there was an activity reduction with the recovery, the levels were kept high. In BRS Macota, PDC activity increased with hypoxia and it was maintained higher than control, even after $72 \mathrm{~h}$ of recovering (Figure 3B).

LDH activity in Fundacep 53 RR nodules was similar to PDC, with an increase of activity with hypoxia that did not return to control levels at $72 \mathrm{~h}$ of recovering. LDH activity in BRS Macota nodules increased under hypoxia and reduced only at $72 \mathrm{~h}$ of returning to normoxia, and did not continue decreasing down to prehypoxic levels (Figure 3C).

\section{Anaerobic metabolites levels}

Ethanol levels in roots increased with hypoxia and became higher at $24 \mathrm{~h}$ of recovering in both genotypes (Figures 4 and 5). Nevertheless, within $72 \mathrm{~h}$ of returning 
to normoxia conditions, ethanol levels decreased to prehypoxic levels in Fundacep $53 \mathrm{RR}$ and, despite reducing in BRS Macota, remained higher than control (Figure 4A). Lactate levels in roots of both genotypes increased during hypoxia. However, in BRS Macota this increase was more expressive regarding control within $24 \mathrm{~h}$ of hypoxia. Lactate levels decreased with the recovery in both genotypes reaching pre-hypoxic levels at $72 \mathrm{~h}$ of normoxia (Figure 4B). Pyruvate levels were kept at control levels in both genotypes at $24 \mathrm{~h}$ of hypoxia, decreasing at $72 \mathrm{~h}$. After returning to normoxia, levels were re-established to control levels only in Fundacep 53 RR (Figure 4C).

Ethanol levels were not influenced by hypoxia in nodules of either genotype. However, in Fundacep 53 $\mathrm{RR}$ an increase at $24 \mathrm{~h}$ of recovery and a subsequent decrease to pre-hypoxic levels were observed. At $72 \mathrm{~h}$ of normoxia, in BRS Macota a decrease in ethanol levels regarding control was observed with the return to normoxia (Figure 5A).

Lactate levels in Fundacep 53 RR increased only at $72 \mathrm{~h}$ of hypoxia, whereas in BRS Macota, they increased at $24 \mathrm{~h}$ of hypoxia, remaining high at $72 \mathrm{~h}$. In both genotypes, lactate levels decreased to pre-hypoxic levels at $24 \mathrm{~h}$ from recovery (Figure 5B). Pyruvate levels in nodules, differently from roots, increased in Fundacep 53 $\mathrm{RR}$ with hypoxia (24 and $72 \mathrm{~h}$ ) re-establishing at $72 \mathrm{~h}$ from recovery. In BRS Macota no alteration regarding this metabolite was found (Figure 5C).

\section{Carbohydrate levels}

Total soluble sugar contents (TSS) in the roots of Fundacep 53 RR did not alter in hypoxia and recovery treatments (Figures 6 and 7). Although levels decreased at $24 \mathrm{~h}$ of hypoxia and increased with a return to nor-
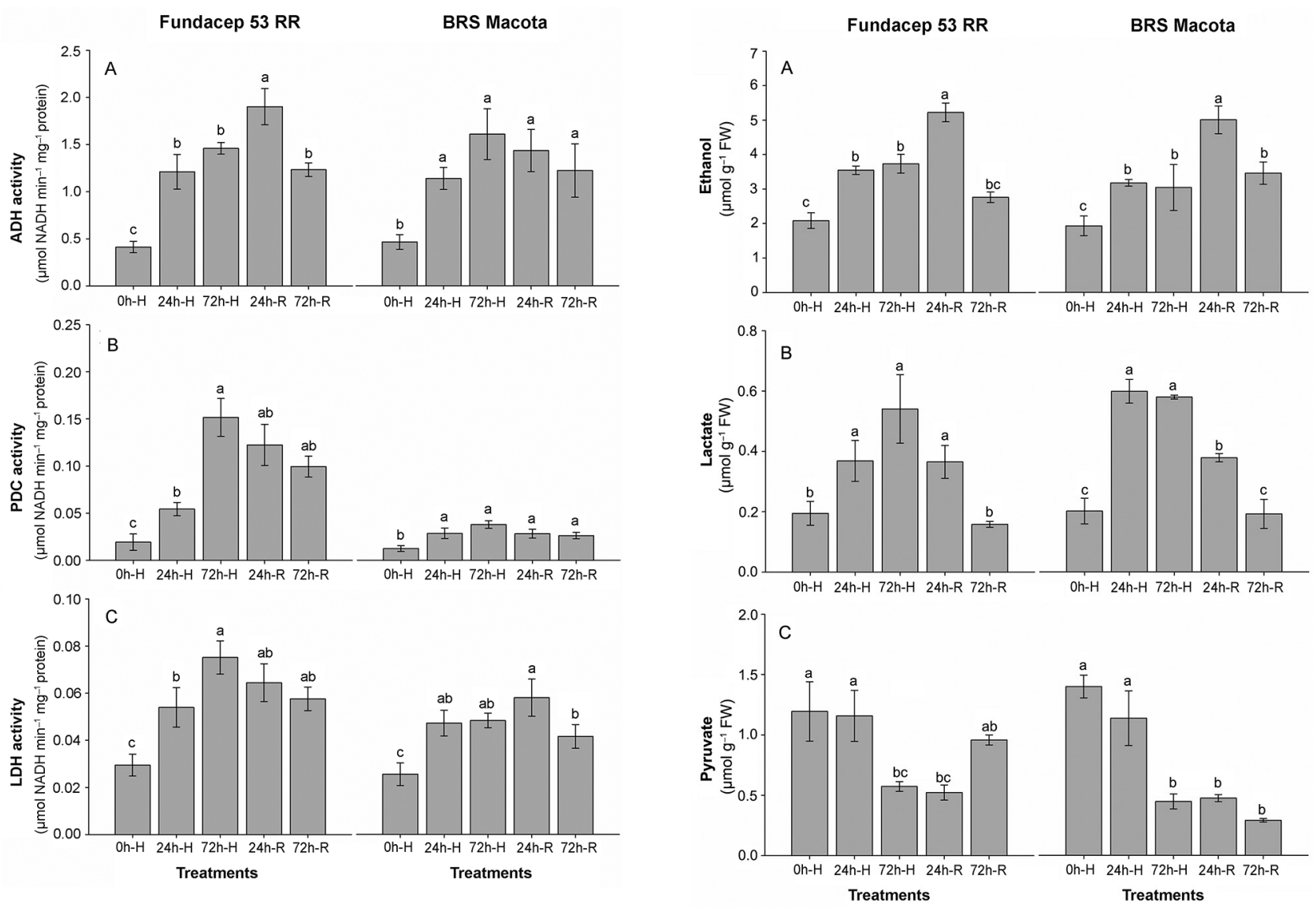

Figure 3 - Enzyme activities from nodules of soybean genotypes (Fundacep 53 RR and BRS Macota) as induced by hypoxia and post-hypoxia conditions. Alcohol dehydrogenase - $A D H(A)$, pyruvate decarboxylase - PDC (B) and lactate dehydrogenase - LDH (C). Hypoxia (Oh-H, 24-H and 72-H) and recovery (24h-R and 72h-R). The bars mean value \pm SD as determined from four biological replicates. Values that differ according to a one-way ANOVA $(p \leq 0.05)$ and Tukey posthoc test are marked with different small letters.

Figure 4 - Metabolites from roots of soybean genotypes (Fundacep 53 RR and BRS Macota) as induced by hypoxia and post-hypoxia conditions. Ethanol (A), lactate (B) and pyruvate (C). Hypoxia (Oh-H, 24-H and 72-H) and recovery (24h-R and 72h-R). The bars mean value \pm SD as determined from four biological replicates. Values that differ according to a one-way ANOVA ( $p \leq 0.05)$ and Tukey posthoc test are marked with different small letters. 

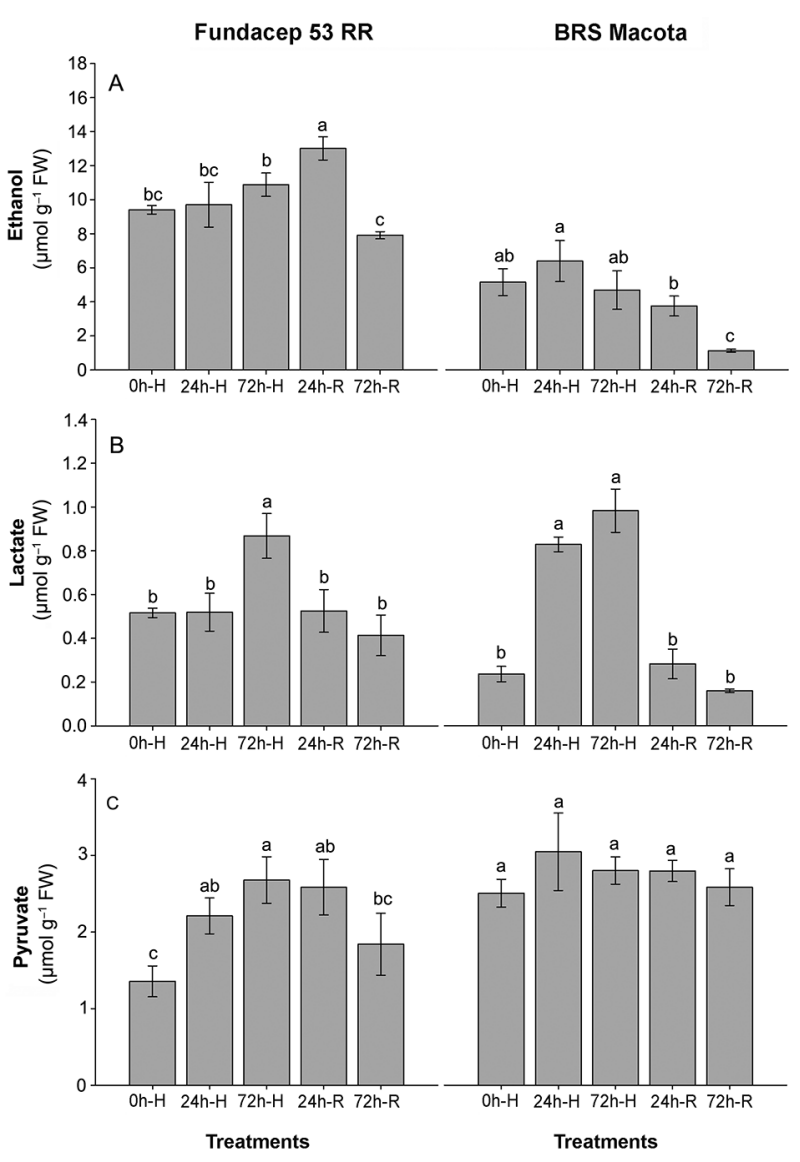

Figure 5 - Metabolites from nodules of soybean genotypes (Fundacep 53 RR and BRS Macota) as induced by hypoxia and post-hypoxia conditions. Ethanol (A), lactate (B) and pyruvate (C). Hypoxia (Oh-H, 24- $\mathrm{H}$ and $72-\mathrm{H}$ ) and recovery (24h-R and 72h-R). The bars mean value $\pm S D$ as determined from four biological replicates. Values that differ according to a one-way ANOVA $(p \leq 0.05)$ and Tukey posthoc test are marked with different small letters.

moxia, means in BRS Macota did not differ from the control (Figure 6A). However, data variation among treatments was similar to sucrose variation. Sucrose contents in roots of Fundacep $53 \mathrm{RR}$ increased with $72 \mathrm{~h}$ of hypoxia and decreased with recovery at control levels. In BRS Macota sucrose contents decreased in the first 24 $\mathrm{h}$ of hypoxia, reestablishing levels similar to the control level for the other treatments (Figure 6B). In Fundacep $53 \mathrm{RR}$ roots no alterations in the water soluble polysaccharide contents (WSP) during hypoxia or recovery periods evaluated were observed; however, in BRS Macota there was a decrease at $24 \mathrm{~h}$ of hypoxia, remaining constant even after $24 \mathrm{~h}$ of return to normoxia, reestablishing at $72 \mathrm{~h}$ (Figure 6C). Starch root levels in Fundacep $53 \mathrm{RR}$ increased at $24 \mathrm{~h}$ of hypoxia and decreased at 72 h. Under normoxia starch levels increased again. In BRS Macota, starch levels increased with $72 \mathrm{~h}$ of recovery (Figure 6D).
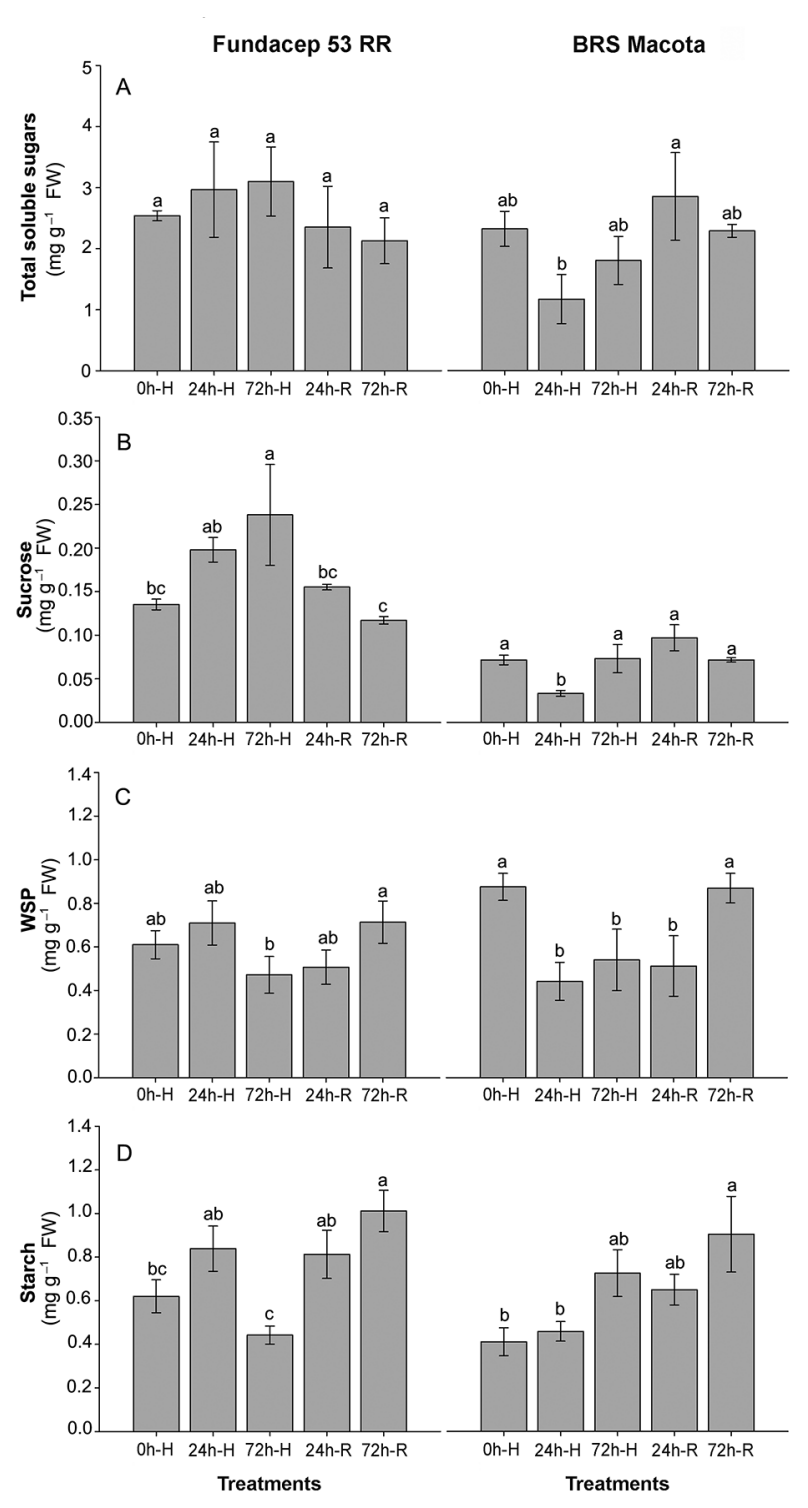

Figure 6 - Carbohydrate content from roots of soybean genotypes (Fundacep 53 RR and BRS Macota) as induced by hypoxia and post-hypoxia conditions. Total soluble sugar (A), sucrose (B), water soluble polysaccharides (C) and starch (D). Hypoxia (Oh-H, 24-H and $72-\mathrm{H}$ ) and recovery (24h-R and $72 \mathrm{~h}-\mathrm{R})$. The bars mean value \pm $\mathrm{SD}$ as determined from four biological replicates. Values that differ according to a one-way ANOVA ( $p \leq 0.05$ ) and Tukey posthoc test are marked with different small letters.

TSS levels in nodules decreased during hypoxia in both genotypes and returned to pre-hypoxic levels during recovery at $24 \mathrm{~h}$ of post-hypoxia in BRS Macota and $72 \mathrm{~h}$ in Fundacep 53 RR (Figure 7A). Sucrose levels decreased slightly under hypoxia and returned to control levels at $72 \mathrm{~h}$ of recovery in Fundacep $53 \mathrm{RR}$. On the other hand, in BRS Macota, sucrose levels remained similar to control levels during hypoxia and increased with 

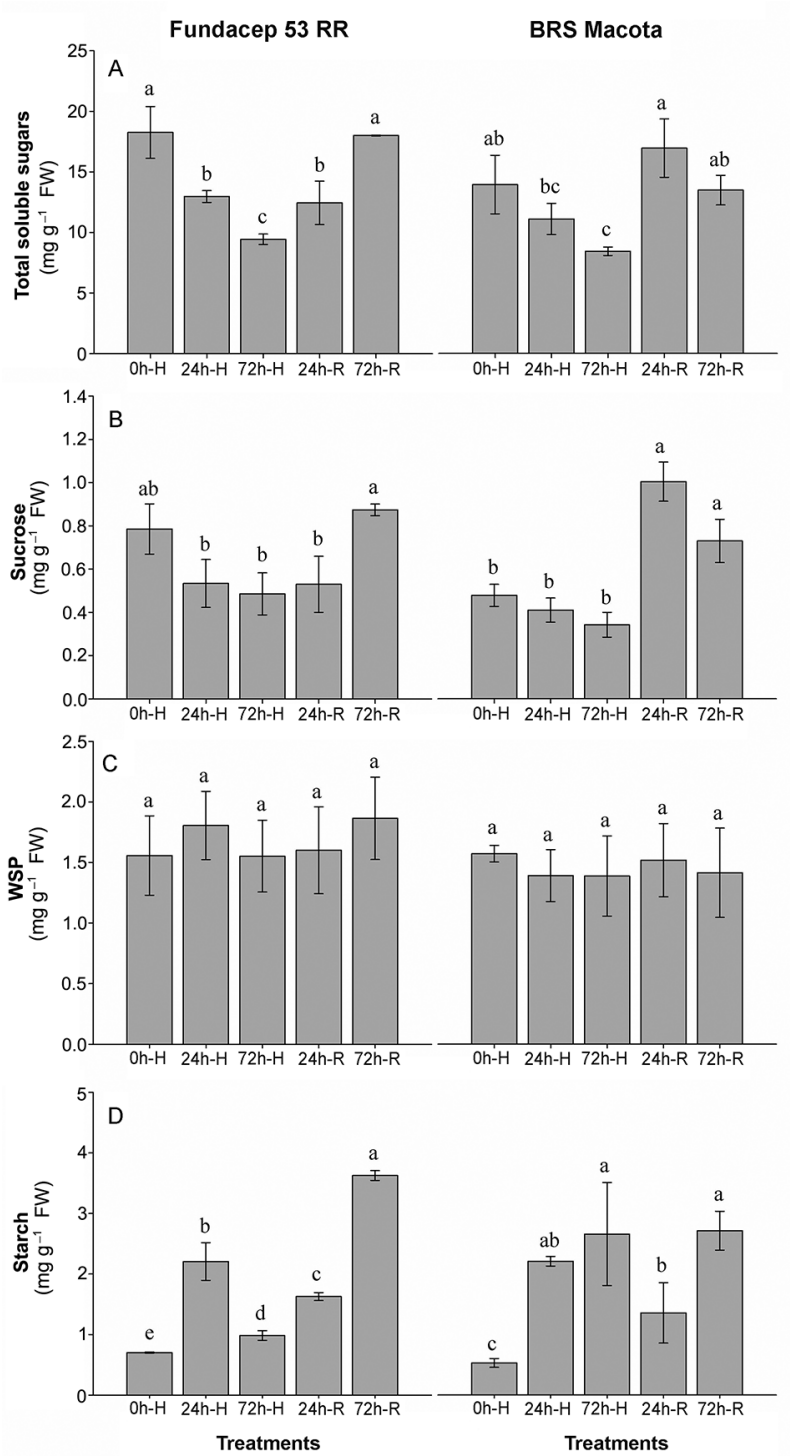

Figure 7 - Carbohydrate content from nodules of soybean genotypes (Fundacep 53 RR and BRS Macota) as induced by hypoxia and post-hypoxia conditions. Total soluble sugar (A), sucrose (B), water soluble polysaccharides (C) and starch (D). Hypoxia (Oh-H, 24-H and $72-\mathrm{H}$ ) and recovery (24h-R and 72h-R). The bars mean value \pm $\mathrm{SD}$ as determined from four biological replicates. Values that differ according to a one-way ANOVA ( $p \leq 0.05$ ) and Tukey posthoc test are marked with different small letters.

recovery to values higher than control levels (Figure 7B). WSP nodule levels remained unaltered during hypoxia and post-hypoxia in both genotypes (Figure 7C). Starch levels in Fundacep 53 RR nodules increased during the $24 \mathrm{~h}$ of hypoxia and decreased in remaining times until $72 \mathrm{~h}$ of recovery, when they increased drastically. In BRS Macota, starch levels increased during hypoxia, decreased with $24 \mathrm{~h}$ of recovery and increased again with $72 \mathrm{~h}$ of recovery (Figure $7 \mathrm{D}$ ).

\section{Discussion}

Mitochondrial oxidative phosphorylation is inhibited when aerobic organisms are deprived of $\mathrm{O}_{2}$ (Zabalza et al., 2009), while the glycolysis and fermentative pathways are activated, leading to accumulation of several metabolites, such as pyruvate, lactate, ethanol, alanine (Ala) and others (Fan et al., 1997; Sousa and Sodek, 2002b; Rocha et al., 2010a). Although $\mathrm{O}_{2}$ levels were not completely depleted in nutrient solution, even after 24 $\mathrm{h}$ from hypoxia (Figure 1), the amount of $\mathrm{O}_{2}$ that could be consumed by the roots is almost nil, as $\mathrm{O}_{2}$ levels decrease at extremely low values and the diffusion rate in water is 10,000 times lower than in the air (Armstrong et al., 1994, 2009; Bailey-Serres et al., 2012).

Responses to oxygen deficit have been studied in soybean, as well as in several other species. Low oxygen level causes fast changes in gene transcription, protein synthesis and degradation and cellular metabolism (Bailey-Serres and Voesenek, 2008; Komatsu et al., 2009, Komatsu et al., 2010).

A sudden increase in $\mathrm{ADH}$ activity (Figures $2 \mathrm{~A}$ and $3 \mathrm{~A})$ as well as in roots and nodules of Fundacep $53 \mathrm{RR}$ and BRS Macota genotypes under hypoxia can be related to the adh gene, the main gene involved in plant fermentation (Christianson et al., 2010). In soybean seedlings it was up-regulated by more than 10,000 fold after $12 \mathrm{~h}$ of flooding when compared to controls. It was suggested that the early response of soybean under flooding might be important stress adaptation to ensure survival under hypoxia (Komatsu et al., 2009).

ADH activity in cotton roots increased in up to 48 $\mathrm{h}$ post-hypoxia and only after this period, declined (Millar et al., 1994), returning to pre-hypoxic levels with 120 h of normoxia (Millar and Dennis, 1996). This response was similar to the one verified in soybean roots (Figure 2A) and nodules (Figure 3A), where the effects of oxygen deprivation were more intense, with an $\mathrm{ADH}$ activity increase in Fundacep 53 RR nodules even after 24 h of return to normoxia or a slow decline of the enzyme activity in post-hypoxic roots, failing to reach pre-hypoxic levels even after $72 \mathrm{~h}$ of recovery in either genotype.

High ethanol levels in roots and nodules (Figures $4 \mathrm{~A}$ and $5 \mathrm{~A}$ ) are related to high $\mathrm{ADH}$ activity in these organs under hypoxia. Ethanol levels were kept high even after the return to normoxia, resulting from the slow decline of $\mathrm{ADH}$ activity. Low ethanol levels in BRS Macota nodules (Figure 5A) can be a result of advanced tissue senescence due to the time of exposure to oxygen deficit (in nodules with $72 \mathrm{~h}$ of hypoxia which had deteriorated). This was not observed in Fundacep 53 RR.

Studies with Arabidopsis thaliana show that an increase in gene expression and ADH and PDC activities are essential to hypoxia tolerance (Kursteiner et al., 2003; Bieniawska et al., 2007). In soybean seedlings, oxygen deficit induced an accumulation of ADH mRNA, selective synthesis of ADH protein and increase of enzyme activity (Russell et al., 1990). Up regulation of $\mathrm{ADH}$ 
and PDC genes detected by transcriptome techniques in soybean under flooding suggest that these genes are involved in the perception of oxygen deprivation and exhibit a similar enzyme cascade as other species under hypoxia (Komatsu et al, 2009).

In figures 2 and 3, similar behavior can be observed for $\mathrm{ADH}$ and $\mathrm{PDC}$, showing strong increases in activities at $72 \mathrm{~h}$, mainly in Fundacep $53 \mathrm{RR}$. These enzymes are responsible for ethanol production, the major fermentation product in tissues of higher plants that determine tolerance to oxygen deficiency. It is produced by PDC through oxidation and decarboxylation of pyruvate in acetaldehyde that is the $\mathrm{ADH}$ substrate for the production of ethanol (Good and Crosby, 1989). Ethanol levels usually found in plants are not enough to cause toxicity. On the other hand, it is not easily metabolized and since it is soluble in the lipid bilayer of membrane cells (Drew, 1997), it can be almost totally diffused out of the cell, resulting in carbon loss (Good and Crosby, 1989; Perata and Alpi, 1993; Rocha et al., 2010a). However, as regards efficiency, ethanol pathway formation is more important than lactate pathway formation, as it promotes more $\mathrm{NAD}^{+}$regeneration and consumption of protons (Kato-Noguchi, 2000).

$\mathrm{LDH}$ is induced by hypoxia and its product - lactate - are generally produced before ethanol, soon after the plant is under hypoxia, promoting cytosol acidification (Kato-Naguchi, 2000). Cytosolic pH decrease (Drew, 1997) signals ethanol production, once PDC is activated when $\mathrm{pH}$ decreases and $\mathrm{ADH}$ is activated under hypoxia (Good and Crosby, 1989). LDH activity increase was followed by a rise in lactate level (Figures 2C, 3C, 4B and 5B) in both genotypes and tissues. This happened in the first $24 \mathrm{~h}$ of hypoxia, decreasing with the return to normoxia. $\mathrm{ADH}$ and PDC activity increased considerably at $72 \mathrm{~h}$ of hypoxia up to $24 \mathrm{~h}$ post-hypoxia, followed by its respective metabolite, ethanol. Therefore, change in lactate fermentation to alcoholic fermentation represents an important indicator of the ability of a plant to survive hypoxia without extensive cell damage (Mustroph et al., 2006, 2010).

BRS Macota was more sensitive to waterlogging while Fundacep $53 \mathrm{RR}$ was more tolerant to hypoxia and post-hypoxia effects, which can be confirmed by changes in enzymatic activity. Fundacep $53 \mathrm{RR}$ is more responsive to normoxia return, showing a faster decrease of fermentative enzymes activity near to pre-hypoxic levels (Figure 2). Nevertheless BRS Macota even after return to normoxia has continued with higher $\mathrm{ADH}$ activity in comparison to Fundacep $53 \mathrm{RR}$ (Figures 2A and 3A).

Lactate levels in BRS Macota were higher than Fundacep $53 \mathrm{RR}$ during hypoxia treatment at $24 \mathrm{~h}$, in both roots and nodules (Figures $4 \mathrm{~B}$ and $5 \mathrm{~B}$ ). Lactate is toxic for the cells and leads to acidification of the cytosol (Rocha et al., 2010a). Ethanol levels decreased faster in roots of Fundacep $53 \mathrm{RR}$ than BRS Macota at $72 \mathrm{~h}$ of recovery (Figure 4A) similar to ADH activity (Figure 2A). Fundacep $53 \mathrm{RR}$ also showed higher levels of carbohydrates (TSS and sucrose - Figure 6A, B) in roots during hypoxia, which may have contributed to better tolerance in relation to BRS Macota.

Pyruvate is a common substrate for ethanol and lactate production. Pyruvate accumulation is a result of a decrease in oxidation rate and increase of synthesis, as has been observed in non-nodulated soybean roots (Sousa and Sodek, 2002b) and hypoxic barley roots (Good and Muench, 1993). However, a differentiated behavior in the genotypes used can be observed, once they are nodulated plants which show a metabolic mechanism distinct from non-nodulated plants.

Pyruvate levels increased in nodules (Figure 5C) and decreased in roots (Figure 4C). It can be related in nodules, to an increase in carbohydrate oxidation rate, mainly sucrose (Figure 7B) and TSS (Figure 7D). The low pyruvate levels in roots can be related to sucrose level increases (Figure 6B), TSS (Figure 6D) and starch (Figure $6 \mathrm{~A})$, at least in the first $24 \mathrm{~h}$ of hypoxia, and are probably attributable to the differentiated metabolism of both tissues and the need to supply cell energy demand as can be seen in the works of Fan et al. (1988) and Reggiani et al. (2000).

The highest pyruvate oxidation rate in roots also resulted in the highest lactate production rate (Figure 4B) and ethanol (Figure 4A) under hypoxia in relation to pre-hypoxic levels. A third pathway is also activated under hypoxia and uses pyruvate as substrate to amino acids production as alanine, catalyzed by alanine aminotransferase (AlaAT) and GABA ( $\gamma$-aminobutyric acid) (Sousa and Sodek, 2003; Miyashita et al., 2007; Dongen et al., 2009; Rocha et al., 2010a, b). Increases in the activity of AlaAT and alanine production under hypoxia is much more expressive in soybean roots than nodules (Rocha et al., 2010b), which could explain why there is a reduction in the pyruvate levels in roots (Figure $4 \mathrm{C}$ ) and not in nodules (Figure 5C).

Although $\mathrm{ADH}, \mathrm{PDC}$ and LDH activity induction can contribute to survival and compensate the shortage of energy by carbohydrate fermentation to keep ATP production in the absence of oxygen (Wang et al., 2009), the benefit under such conditions will depend on the kind of tissue, developmental stage, species, genotype, stress severity and length (Fukao and Bailey-Serres, 2004; Wang et al., 2009) and ability to recover normal function after a hypoxic stress period (Henshaw et al., 2007). Generally, species or genotypes that show higher concentration of carbohydrates in the roots and an efficient metabolic mechanism associated with its mobilization through fermentative metabolism, show higher tolerance to support oxygen deficiency (Sairam et al., 2009; Araki et al., 2012).

In species susceptible to hypoxia there is a decrease in the carbohydrate levels, such as sugars and sucrose due to higher ATP consumption by cells to metabolism maintenance, while in more tolerant species there is an increase in carbohydrate levels, especially sugars and sucrose, also related to the increase of enzyme activity of carbohydrate metabolism, such as sucrose synthase 
(Susy) (Kennedy et al., 1992). Susy is a key enzyme responsible for reversible hydrolysis of sucrose in fructose and glucose that are substrates to the glycolysis pathway, the main source of energy under hypoxia (Kumutha et al., 2008). Concomitant to the increase of Susy activity, there is a decrease in invertase activity in hypoxia-tolerant species (Springer et al., 1986).

In waterlogged pigeonpea [Cajanus cajan (L.) Mfllsp] roots, there was a decrease in activity and expression of Susy and ADH in susceptible genotypes and an increase in the tolerant genotypes, followed by carbohydrates levels (Kumutha et al., 2008). Similar effects are also reported in bean roots under hypoxia (Sairam et al., 2009). Therefore, the increase in sugars and sucrose (Figure 6) in Fundacep $53 \mathrm{RR}$ roots may have contributed to higher tolerance to the hypoxia effects and consequently supplied the plant with the energy resources after normoxia return.

In soybean plants subjected to waterlogging of the root system, nodule metabolic activity is severely impaired by waterlogging, almost immediately (Amarante and Sodek, 2006), while roots become hypoxic only after a number of hours (Sousa and Sodek, 2003). Despite oxygen limitation even under normal conditions (Hunt et al., 1989), nodules have an efficient mechanism for transporting oxygen to supply both bacterioid respiration and energy for nitrogen fixation. Oxygen deficiency in the nodule is completely different from a waterlogged root, mainly due to the mechanism that involves leghemoglobin that facilitates nodule activity under low oxygen concentrations (Sousa and Sodek, 2002b), which is related to higher effects of hypoxic treatment on nodule fermentative activity and their lower rate of return to pre-hypoxic metabolism in relation to the roots.

\section{Conclusions}

Fundacep 53 RR and BRS Macota soybean genotypes respond to oxygen depletion effects and maintain high fermentative rates, as shown by fermentative enzyme activities and anaerobic metabolite levels and carbohydrates. Fundacep 53 RR genotype presents higher tolerance to hypoxia effects than BRS Macota, reestablishing more rapidly enzyme activities and restoring metabolite levels to pre-hypoxic levels.

\section{Acknowledgements}

We are grateful to Embrapa/Monsanto partnership and Coordination for the Improvement of Higher Level Personnel (CAPES) for financial support and Agricultural and Livestock Research State Foundation (FEPAGRO) for providing Bradyrhizobium elkanii strain.

\section{References}

Amarante, L.; Sodek, L. 2006. Waterlogging effect on xylem sap glutamine of nodulated soybean. Biologia Plantarum 50: 405410.
Araki, H.; Hossain, M.A.; Takahashi, T. 2012. Waterlogging and hypoxia have permanent effects on wheat root growth and respiration. Journal of Agronomy and Crop Science 198: 264-275.

Armstrong, W.; Strange, M.E.; Cringle, S.; Beckett, P.M. 1994. Microelectrode and modeling study of oxygen distribution in roots. Annals of Botany 74: 287-299.

Armstrong, W.; Webb, T.; Darwent, M.; Beckett, P.M. 2009. Measuring and interpreting respiratory critical oxygen pressures in roots. Annals of Botany 103: 281-293.

Bailey-Serres, J.; Fukao, T.; Gibbs, D.J.; Holdsworth, M.J.; Lee, S.C.; Licausi, F.; Perata, P.; Voesenek, L.A.C.J.; Dongen, J.T. van. 2012. Making sense of low oxygen sensing. Trends in Plant Science 17: 129-138.

Bailey-Serres, J.; Voesenek, A.C.J. 2008. Flooding Stress: acclimations and genetic diversity. Annual Review of Plant Biology 59: 313-339.

Bieleski, R.L.; Turner, N.A. 1966. Separation and estimation of amino acids in crude plant extracts by thin-layer electrophoresis and chromatography. Analytical Biochemistry 17: 278-293.

Bieniawska, Z.; Barratt, D.H.P.; Garlick, A.P.; Thole, V.; Kruger, N.J.; Martin, C. 2007. Analysis of the sucrose synthase gene family in Arabidopsis. Plant Journal 49: 810-828.

Bradford, M.M. 1976. Rapid and sensitive method for the quantitation of microgram quantities of protein utilizing the principle of protein-dye binding. Analytical Biochemistry 72: 248-254.

Christianson, J.A.; Llewellyn, D.J.; Dennis, E.S.; Wilson, I.W. 2010. Global gene expression responses to waterlogging in roots and leaves of cotton (Gossypium hirsutum L.). Plant Cell Physiology 51: 21-37.

Dongen, J.T. van; Schurr, U.; Pfister, M.; Geigenberger, P. 2003. Phloem metabolism and function have to cope with low internal oxygen. Plant Physiology 131: 1529-1543.

Dongen, J.T. van; Fröhlich, A.; Ramírez-Aguilar, S.J.; Schauer, N.; Fernie, A.R.; Erban, A. 2009. Transcript and metabolite profiling of the adaptive response to mild decreases in oxygen concentration in the roots of Arabidopsis plants. Annals of Botany 103: 269-280.

Drew, M.C. 1997. Oxygen deficiency and root metabolism: injury and acclimation under hypoxia and anoxia. Annual Review of Plant Physiology and Plant Molecular Biology 48: 223-250.

Fan, T.W.M.; Higashi, R.M.; Frenkiel, T.A.; Lane, A.N. 1997. Anaerobic nitrate and ammonium in flood-tolerant rice coleoptiles. Journal of Experimental Botany 48: 1655-1666.

Fan, T.W.M.; Higashi, R.M.; Lane, A.N. 1988. An in vivo $1 \mathrm{H}$ and 31P NMR investigation of the effect of nitrate on hypoxic metabolism in maize roots. Archives of Biochemistry and Biophysics 266: 592-606.

Fehr, W.R.; Caviness, C.E.; Burmood, D.T.; Pennington, J.S. 1971. Stage of development descriptions for soybeans, Glycine max (L.) Merril. Crop Science 11: 929-931.

Fukao, T.; Bailey-Serres, J. 2004. Plant responses to hypoxia. Is survival a balancing act? Trends in Plant Science 9: 1403-1409.

Geigenberger, P. 2003. Response of plant metabolism to too little oxygen. Current Opinions in Plant Biology 6: 247-256.

Githiri, S.M.; Watanabe, S.; Harada, K.; Takahashi, R. 2006. QTL analysis of flooding tolerance in soybean at an early vegetative growth stage. Plant Breeding 125: 613-618. 
Good, A.G.; Crosby, W.L. 1989. Anaerobic induction of alanine aminotransferase in barley root tissue. Plant Physiology 90: 1305-1309.

Good, A.G.; Muench, D.G. 1993. Long-term anaerobic metabolism in root tissue. Plant Physiology 101: 1163-1168.

Graham, D.; Smydzuc, J. 1965. Use of anthrone in the quantitative determination of hexose phosphates. Analytical Biochemistry 11: 246255.

Handel, E.V. 1968. Direct microdetermination of sucrose. Analytical Biochemistry 22: 280-283.

Hanson, A.D.; Jacobsen, J.V.; Zwar, J.A. 1984. Regulated expression of three alcohol dehydrogenase genes in barley aleurone layers. Plant Physiology 75: 573-581.

Hanson, A.D.; Jacobsen, J.V. 1984. Control of lactate dehydrogenase, lactate glycolysis, and $\alpha$-amilase by $\mathrm{O}_{2}$ deficit in barley aleurone layers. Plant Physiology 74: 566-572.

Henshaw, T.L.; Gilbert, R.A.; Scholberg, J.M.S.; Sinclair, T.R. 2007. Soya bean (Glycine max L. Merr.) genotype response to early-season flooding. I. Root and nodule development. Journal of Agronomy and Crop Science 193: 177-188.

Horchani, F.; Khayati, H.; Raymond, P.; Brouquisse, R.; Aschi-Smiti, S. 2009. Contrasted effects of prolonged root hypoxia on tomato root and fruit (Solanum lycopersicum) metabolism. Journal of Agronomy and Crop Science 195: 313-318.

Hunt, S.; King, B.J.; Layzell, D.B. 1989. Effects of gradual increases in $\mathrm{O}_{2}$ concentration on nodule activity in soybean. Plant Physiology 91: 315-321.

Jackson, M.B.; Colmer, T.D. 2005. Response and adaptation by plants to flooding stress. Annals of Botany 96: 501-505.

Kato-Naguchi, H. 2000. Evaluation of the importance of lactate for the activation of ethanolic fermentation in the lettuce in anoxia. Plant Physiology 109: 28-33.

Kennedy, R.A.; Rumpho, M.E.; Fox, T.C. 1992. Anaerobic metabolism in plants. Plant Physiology 100: 1-6.

Kokubun, M. 2013. Genetic and cultural improvement of soybean for waterlogged conditions in Asia. Field Crops Research 152: 3-7.

Kolb, R.M.; Joly, C.A. 2009. Flooding tolerance of Tabebuia cassinoides: metabolic, morphological and growth responses. Flora 204: 528-535.

Komatsu, S.; Sugimoto, T.; Hoshino, T.; Nanjo, Y.; Furukawa, K. 2010. Identification of flooding stress responsible cascades in root and hypocotyl of soybean using proteome analysis. Amino Acids 38: 729-738.

Komatsu, S.; Yamamoto, R.; Nanjo, Y.; Mikami, Y.; Yonukawa, H.; Sakata, K. 2009. A comprehensive analysis of the soybean genes and proteins expressed under flooding stress using transcriptome and proteome techniques. Journal of Proteome Research 8: 4766-4778.

Kumutha, D.; Sairam, R.K.; Ezhilmathi, K.; Chinnusamy, V.; Meena, R.C. 2008. Effect of waterlogging on carbohydrate metabolism in pigeon pea (Cajanus cajan L.): upregulation of sucrose synthase and alcohol dehydrogenase. Plant Science 175: 706-716.

Kursteiner, O.; Dupuis, I.; Kuhlemeier, C. 2003. The pyruvate decarboxylase 1 gene of Arabidopsis is required during anoxia but not other environmental stresses. Plant Physiology 132: 968-978.

Lima, J.D.; Sodek, L. 2003. N-stress alters aspartate and asparagine levels of xylem sap in soybean. Plant Science 165: 649-656.
McCready, R.M.; Guggols, J.; Silveira, V.; Owens, H.S. 1950. Determination the starch and amilose in vegetables: applications to pea. Analytical Chemistry 22: 1156-1158.

Millar, A.A.; Dennis, E.S. 1996. Protein synthesis during oxygen deprivation in cotton. Australian Journal of Plant Physiology 23: 341-348.

Millar, A.A.; Olive, M.R.; Dennis, E.S. 1994. The expression and anaerobic induction of alcohol-dehydrogenase in cotton. Biochemical Genetics 32: 279-300.

Miyashita, Y.; Dolferus, R.; Ismond, K.P.; Good, A.G. 2007. Alanine aminotransferase catalyses the breakdown of alanina after hypoxia in Arabidopsis thaliana. Plant Journal 49: 11081121.

Mustroph, A.; Boamfa, E.I.; Laarhoven, L.J.J.; Harren, F.J.M.; Albrecht, G.; Grimm, B. 2006. Organ-specific analysis of the anaerobic primary metabolism in rice and wheat seedlings. I. Dark ethanol production is dominated by the shoots. Planta 225: 103-114

Mustroph, A.; Lee, S.C.; Oosumi, T.; Zanetti, M.E.; Yang, H..; Ma, K.; Yaghoubi-Masihi, A.; Fukao, T.; Bailey-Serres, J. 2010. Cross-kingdom comparison of transcriptomic adjustments to low-oxygen stress highlights conserved and plant-specific responses. Plant Physiology 152: 1484-1500.

Oliveira, H.C.; Freschi, L.; Sodek, L. 2013. Nitrogen metabolism and translocation in soybean plants subjected to root oxygen deficiency. Plant Physiology and Biochemistry 66: 141-149.

Perata, P.; Alpi, A. 1993. Plant responses to anaerobiosis. Plant Science 93: 1-17.

Puiatti, M.; Sodek, L. 1999. Waterlogging affects nitrogen transport in the xylem of soybean. Plant Physiology and Biochemistry 37: 767-773.

Reggiani, R.; Nebuloni, M.; Mattana, M.; Brambilla, I. 2000. Anaerobic accumulation of amino acids in rice roots: role of the glutamine synthetase/glutamate synthase cycle. Amino Acids 18: 207-217.

Rocha, M.; Licausi, L.; Araújo, W.L.; Nunes-Nesi, A.; Sodek, L.; Fernie, A.R.; Dongen, J.T. van. 2010a. Glycolysis and the tricarboxylic acid cycle are linked by alanine aminotransferase during hypoxia induced by waterlogging of Lotus japonicus. Plant Physiology 152: 1501-1513.

Rocha, M.; Sodek, L.; Licausi, F.; Hameed, M.W.; Dornelas, M.C.; Dongen, J.T. van. 2010b. Analysis of alanine aminotransferase in various organs of soybean (Glycine max) and in dependence of different nitrogen fertilisers during hypoxic stress. Amino Acids 39: 1043-1503.

Russell, D.A.; Wong, D.M.-L.; Sachs, M.M. 1990. The anaerobic response of soybean. Plant Physiology 92: 401-407.

Sairam, R.K.; Kumutha, D.; Viswanathan, C.; Ramesh, C.M. 2009. Waterlogging-induced increase in sugar mobilization, fermentation, and related gene expression in the roots of mung bean (Vigna radiata). Journal of Plant Physiology 166: 602-616.

Sousa, C.A.F.; Sodek, L. 2002a. Metabolic changes in soybean plants in response to waterlogging in the presence of nitrate. Physiology Molecular Biology of Plants 8: 97-104.

Sousa, C.A.F.; Sodek, L. 2002b. The metabolic response of plants to oxygen deficiency. Brazilian Journal of Plant Physiology 14: 83-94. 
Sousa, C.A.F.; Sodek, L. 2003. Alanine metabolism and alanine aminotransferase activity in soybean (Glycine max) during hypoxia of the root system and subsequent return to normoxia. Environmental and Experimental Botany 50: 1-8.

Springer, B.; Werr, B.; Starlinger, P.; Bennett, D.C.; Freeling, M. 1986. The shrunken gene on chromosome 9 of Zea mays L. is expressed in various plant tissues and encode an anaerobic protein. Molecular and General Genetics 220: 461-468.

Tadege, M.; Dupuis, I.; Kuhlemeier, C. 1999. Ethanolic fermentation: new functions for an old pathway. Trends in Plant Science 4: 320-325.
Wang, K.; Bian, S.; Jiang, Y. 2009. Anaerobic metabolism in roots of Kentucky bluegrass in response to short-term waterlogging alone and in combination with high temperatures. Plant and Soil 314: 221-229.

Zabalza, A.; Dongen, J.T. van; Froehlich, A.; Oliver, S.N.; Faix, B.; Gupta, K.J.; Schmäzlin, E.; Igal, M.; Orcaray, L.; Royuela, M.; Geigenberger, P. 2009. Regulation of respiration and fermentation to control the plant internal oxygen concentration. Plant Physiology 149: 1087-1098. 